Journal of Management and Economic
Studies
2019, 1(1): 48-65 DOI: $10.26677 / \mathrm{TR} 1010.2019 .60$
Journal Homepage: $\mathrm{https://wWw.jomaes.org}$

\title{
Impact of Board Characteristics, Audit Committee Characteristics And External Auditor on Disclosure Quality of Financial Reporting
}

\author{
Ali Thamer Nawafly \\ Al-Nahrain University, Iraq \\ Ali Saleh Alarussi \\ Xiamen University Malaysia, Malaysia, al_arussi@yahoo.com
}

\begin{abstract}
This study has been conducted to identify the factors that influence disclosure quality of financial reporting, it focuses on board characteristics, audit committee characteristics, and external audit to ensure financial reporting quality. Seven independent variables have been examined their significant relationships with the disclosure quality of financial reporting of companies in Malaysia. The independent variables are Board composition, Board size, Board expertise, Audit committee independence, Audit committee size, Audit committee expertise and External Auditor Characteristics. The study has taken a sample of 150 non-financial listed companies of Bursa Malaysia. It is across sectional study that use the data for companies' annual report for 2014. The regression analysis SPSS is applied to examine the association between independent variables and dependent variable. The findings show that board characteristics, audit committee characteristics and Big Fours have all a significant and a positive impact over disclosure quality of financial reporting. This study besides contributed by supporting agency theory, provided a simplified framework that includes Big Fours as one of the determination of disclosure quality. Due to the time limitation, the data include only 150 companies listed in bursa Malaysia for year 2014. These results benefit internal users (such as mangers, board of directors and shareholders. They can realize the characteristics of board of directors and audit committee that enhance the disclosure quality of financial reporting. This is important especially after the depreciation of the Malaysian currency, hence restore the investors' trust. On the other side, external users such as investors, creditors, new established companies, tax authority also may get advantages of these results. It is clear that those users care about solid information with high quality to make their decisions after the first currency's depreciation. This study differs than previous studies in many ways: first, it focuses on nonfinancial listed companies in Malaysia. Previous studies have concentrated on companies in the financial sector, such as banking and financial institutions or on industrial organizations. Second, this study analyzes the data in companies' annual reports for a one-year period which is 2014. Staring from 2014, the economy in Malaysia was fluctuating due to currency
\end{abstract}


depreciation by more than $17.5 \%$ by the end of 2014 . Third, this study measures financial reporting disclosure quality by using a disclosure index, which different than other previous measurements such as earnings response coefficients, bid ask spreads, and audit report lag. Last but not least, this study provides an empirical support evidence for two theories which are agency theory and resource dependency theory.

Keywords: Board of directors, Audit committee, Big Four Audit, Disclosure quality of financial reporting, and Malaysia.

\section{Introduction}

Recent collapses of high profile businesses worldwide have captured great attention of investors, regulators, and academicians. The collapse of high-profiles corporate around the world has been rooted in weakness of the Corporate Governance (CG) and Audit Committee (AC) (Srinivasan, 2005). Disclosure quality of financial reporting is critically significant for the progress and development the investors 'confidence. Firms with good quality of Financial Reporting (FR) experience significantly better share price performance (Penman, 2007). Disclosure quality is considered to be an important mechanism in reducing information irregularity between firm and investors (Jiang, Habib, \& Hu, 2011), and hence improve the disclosure quality transparency (Akhtaruddin \& Haron, 2010). Researchers have also recognized that boards of directors are an important instrument for observing the performance of management and protecting the interests of shareholders and enhancing disclosure quality (Beasley M. S., 1996). According to agency theory another mechanism of corporate governance (CG) is the separation of the roles of the Chief Executive Officer (CEO) and Chairman Board (CB). Besides separation between the $\mathrm{CEO}$ and $\mathrm{CB}$, Auditing Committee (AC) and external audit facilitate the decline in the agency costs and increase the disclosure quality (Beasley M. S., 1996). Other advocates of the separation between the two roles highlighted that cross checks regarding the performance of management through AC and external auditors will ensure quality in FR (Klein, 2002). In addition, AC size and board size are also hypothetically linked with the capability of directors to monitor and govern management (Carcello \& Nagy, 2004), despite the fact that the there is an unclear direction. Along with board of directors and audit committee one of the major players of corporate governance is external auditor. Without the involvement of external auditors corporate frauds are near to impossible (Cadbury, 1992).

In Malaysia, many high-profile cases including corporations like Technology Resources Industries, FA Peninsular, Tat Sang, Time dotcom, and Malaysian Airlines have experienced the failure of CG (Hashim \& Devi, 2008). Recently, market has been disappointed when Securities Commission (SC) Malaysia reprimanded the Mulph International Bhd's Directors failing to disclose information in a 2010 prospectus in a full and true manner (Wind, 2012). Undoubtedly, the series of corporate scandals has shattered the trust of investors in financial markets (Ball, 2006). Regulators, professional bodies, and researchers on disclosure claim that economic crisis worldwide as well as financial scandals in some of the big Malaysian corporations are attributed to the reduction of disclosure quality of FR (Kirkpatrick, 2009). The presence of Malaysian code of CG 2002 has been revised in 2007, and again in 2012. The major changes were suggested in the areas of roles and responsibilities of the board to formalize ethical standards through a code of conduct. The composition of the board should include a Nominating Committee. The committee should be chaired by a senior independent director. Furthermore, independence of the independent directors was further stricken. All these initiatives and efforts reflect the government's desire in developing and enhancing the Malaysian regulatory framework to reinforce the financial and capital market in Malaysia that could distinguish Malaysia from other countries. 
With the latest code revision, it was expected that the disclosure quality of FR will improve however it fails to show a significant improvement in the quality of disclosure (Zahiruddin \& Manab, 2013). Thus, there is an urgent requirement to enhance the quality of FR as the financial markets require clear and true accounting statements to analyze securities which will increase the confidence of investors. Empirically, AC with independent and capable members was found to be able to monitor the internal management disclosure process, leading to fewer internal control problems, more conservatism accounting, less earnings management, fewer incidents of FR fraud and more frequent and higher quality of reporting (Akhtaruddin \& Haron, 2010; Beasley, 1996; Cohen, Hoitash, Krishnamoorthy, \& Wright, 2014). Bédard and Gendron (2010) suggested further research to examine the level of AC independence and board characteristics to improve quality disclosure of FR. Besides, role of big four companies in bringing quality in the FR cannot be ignored. So this study intends to empirically answer the following question: what are the relationships between board characteristics, AC characteristics, and external auditor and the quality disclosure of FR after controlling firm size? In short, this paper empirically examines these factors namely board composition, board size, board expertise, audit committee independence, audit committee size, audit committee expertise and Big Four on the quality of FR after controlling Firm size. The remainder of this paper is structured as follows:- Section 2 provides an overview of quality disclosure and reports a number of previous studies as well as presents the development of the hypotheses while the research method and measurements of variables are described in Section 3, Section 4 discusses the regression analysis results. Finally, section 5 presents the conclusion of this paper and recommendations for future research.

\section{Literature review and hypotheses development}

Studies on quality of Financial Reporting (FR) have seen a vast growth in the few last years. Currently researchers are paying a great attention towards the significance of AC and BOD for improving FR quality (McNeil, Frey \& Embrechts, 2015). Disclosure quality of financial reporting means the fulfillment of disclosure requirements (Singhvi \& Desai, 1971). Disclosure should be made appropriately in the financial statements, footnotes, and management discussion (Abbott, Daugherty, Parker, \& Peters, 2015). Since financial information is critical in this regard. It becomes necessary to assess the extent to which quality reporting is done in preparing the financial statements (Chen, Hope, Li, \& Wang, 2015). In the other hand, investors require information to gage the corporation for making their investment decisions (Johl, Kaur Johl, Subramaniam, \& Cooper, 2013). Therefore, disclosure quality also assists companies in attracting new investors. Along with attracting new investors quality reporting maintains the demand of the company in the share market which ultimately keeps the share prices high (Dehaan, Hodge, \& Shevlin, 2013). Quality reporting decreases information asymmetry between uninformed and informed investors (Goodman, Neamtiu, Shroff, \& White, 2013). While using bid ask news as a proxy for the information asymmetry, García Lara, García Osma, and Penalva (2014) documented a negative relationship between analyst ratings regarding reporting of the firm and bid ask news.

Likewise, Armstrong, Guay, and Weber (2010) highlighted that firms usually enjoy low bid-ask spread after the continual increase reporting ratings by the analyst. Cheng, Liao, and Zhang (2013) found that companies that are committed to higher level of disclosure have relatively lower level of information asymmetry. Companies with better quality reporting enjoy low cost funding in the form of cheaper debt and cheaper equity cost (Albring, Huang, Pereira, \& Xu, 2013). Corporate quality reporting is subject to managers' discretion (Fifka, 2013) and management decides the decision regarding holding or disclosing information regarding tradeoff between the associated proprietary costs of making such reports and the expected benefits of 
informed investors (Gigler, Kanodia, Sapra, \& Venugopalan, 2014). In short, the quality reporting literature revealed that there is a variety of disclosure information that has been discussed in prior study; Firth, Wong, Xin, and Yick (2014) classified reporting in their study with the financial, non-financial perspective and information on outlook, forward looking and historical data. Bertoni, Ferrer, and Martí (2013) analyzed the role of CG played by the Australian companies in the decision regarding disclosure of information in the published annual reports. Furthermore, some of the researchers have classified quality reporting into three types; financial information, strategic information and non-financial information (MartínezFerrero, Garcia-Sanchez, \& Cuadrado-Ballesteros, 2015; Ismail \& King, 2014; Mio \& Venturelli, 2013). This study examines whether the board characteristics, AC characteristics, and external auditor quality are associated with FR disclosure quality.

Although there are a number of theories used to support disclosure quality, this study used only two theories which are agency theory and resource dependency theory as both the theories form the concept of responsibility that is used in the argument in this paper. Board composition and $\mathrm{AC}$ independence including the board size and $\mathrm{AC}$ size are the core factors of agency theory (Eisenhardt, 1989; Hill \& Jones, 1992; Goodman, Neamtiu, Shroff, \& White, 2013). Financial accounting expertise of BOD and AC are supported by resource dependency theory (Hillman \& Dalziel, 2003; Ruigrok, Peck, \& Tacheva, 2007; Cohen \& Krishnamoorthy, 2014).

\section{Board composition}

Board composition is closely related to outside directors sitting in BOD of a company (Nyazeva, Knyazeva, \& Masulis, 2013). It is argued that those independent directors who are free from the influence of the management and who do not have any direct interest in the company, are more effective at decision control (Yoshikawa, Zhu, \& Wang, 2014). Concerning with transparency of FR, Balakrishnan, Billings, Kelly, and Ljungqvist (2014) argued that the number of independent non-executive directors in the board enhances the disclosure quality. Consistently, Daske \& Gebhardt(2006) and Frias-Aceituno, Rodríguez-Ariza, and Garcia-Sánchez (2014) reported a positive relationship among independence of directorate and FR disclosure quality of the company. Hambrick, Misangyi, and Park (2015) have shown that by increasing the number of outside directors the likelihood and chances of frauds can be minimized. Similarly, reported that outside directors are adversely related to accounting enforcement actions, indicating that board composed of outside directors is regarded as an important structure of CG for improving disclosure quality (Firth, Wong, Xin, and Yick,. 2014). This is on the line with the resources dependency theory which states that outside directors' networks, contacts, and connections confer access to necessary strategic resources and information (Ruigrok, Peck, \& Tacheva, 2007) therefore enhance the disclosure quality. In contrary, Ismail and King (2014) reported an insignificant relation between independence of board and FR transparency of a company.

In the Malaysian context, Chen, Cheng, and Wang (2015) argued that there is a significant positive impact of Board composition over the earnings quality, proxied by the coefficients of earnings response. His results supported the effectiveness of independence of directorate as a control mechanism for provision of quality disclosure of FR. Al_arussi et al., (2009) found a positive relationship between non-executive directors in the board and the extent of internet disclosure by companies in Malaysia. Furthermore, Allegrini and Greco (2013) reported a significant linkage between high ratio of independent directors in the board and better quality of audit, proxied with audit fee, improves the disclosure quality. The findings of their study highlight the significance of independent board for better monitoring and improved FR disclosure. However, the findings of Hutchinson, Mack, and Plastow (2015) did not support the above studies and showed some contrary findings between independence of board and accounting issues. Further, Dehaan, Hodge and Shevlin (2013) has shown that higher ratio of 
independent directors in the board appears to worsen audit lag. This study examines the impact of board composition on the quality disclosure of financial reporting. This variable is measured by the ratio of independent non-executive directors relative to the total directors in the board (Beasley, Carcello, Hermanson, \& Neal, 2009; Alzoubi, 2012). Based on the above arguments, the first proposed hypothesis is as follows:

$\mathrm{H}_{1}$ : There is a positive relationship between Board composition and financial reporting disclosure quality.

Board size

According to agency theory, the basic mechanisms to minimize agency cost are more disclosure and appropriate independent board (Fernando, 2009). Empirical findings show that the board size does matter because it impacts monitoring, controlling and decision making in the company (Zona, Zattoni, \& Minichilli, 2013). McDonald and Westphal (2013) argued that larger boards are capable of giving more time and efforts to check the management actions and vice versa. However, there is no consensus in the literature about board size; whether a large number or a smaller board is better. It is argued that the ideal board size if between seven to eight (Cheng, 2008), because such a board can act effectively and efficiently. This is because a small group can easily reach a conclusion (Balakrishnan, Billings, Kelly, \& Ljungqvist, 2014). Hutchinson, Mack, and Plastow (2015) argued that the benefit of higher level monitoring by a huge board may be nullified because of poor decision making by a large board, because of controversies.

In Malaysia, the average number of directors in the boards of companies is eight (Tong, 2014; Ghazali, 2014). Therefore, the size of the board cannot be ignored because the boards of directors are key for the independent and free of influence decisions (Allegrini \& Greco, 2013), and only effective an independent board with an appropriate size can enhance the disclosure quality (Hashim \& Devi, 2008). This variable is measured by the total number of directors on the board of the company (Beasley M. S., 1996; Byard, Li, \& Weintrop, 2006; Cheng S. , 2008; Alzoubi, 2012).Therefore, the second proposed hypothesis is as follows:

$H_{2}$ : There is a relationship between board size and financial reporting disclosure quality.

\section{Board expertise}

Role of board for acting as advisor to the CEO is necessary to enhance value of the organization (Kirkpatrick, 2009). Both internal and external directors should use their expertise and experience to improve FR disclosure quality. This is important for the easy provision of access to finance the company (O'Connor, Priem, Coombs, \& Gilley, 2006). Resources dependency theory guides that performance of the company is not only dependent on the abilities of the management of the company to efficiently manage the resources but also on the capacity of the members to save these resources (Hillman \& Dalziel, 2003). Dehaan, Hodge and Shevlin (2013) argued that the board must have the ability to ask serious questions regarding the actions of management including the areas of risk management, corporate strategy, succession plans of CEO and the questions about meeting the targets for financial and strategic objectives. This is only possible when the board has vital expertise to full all their discussed liabilities. In other words, the expertise of BOD has a significant role in discharging their duties over FR process (Akhtaruddin \& Haron, 2010). This variable is measured based on the total number of past years' experience (Xie, Davidson, \& DaDalt, 2003; Cormier, Magnan, \& Velthoven, 2005). Therefore, the third proposed hypothesis is as follows:

$H_{3}$ : There is a positive relationship between board experience and financial reporting disclosure quality. 


\section{Audit committee independence}

Independent $\mathrm{AC}$ is considered as a key factor which has the capability for the improvement of efficiency of the AC (Carcello, Hermanson, \& Ye, 2011). Importance of independent directors in the AC has always been forced to authenticate the monitoring and controlling of corporate management due to their opportunistic behavior (Armstrong, Guay, \& Weber, 2010). Independent directors are stricter in discharging their responsibilities, and are in a better position to control and face complex situations, because their affiliation is not direct with the management of the company (Brandes, Dharwadkar, \& Suh, 2015), as well as the provision of disclosure quality of financial statements (García Lara, García Osma, \& Penalva, 2014; Chen, Hope, Li, \& Wang, 2015). Based on agency theory, audit committee is considered as an important component for controlling the decisions of the management (Goodman, Neamtiu, Shroff, \& White, 2013)

In Malaysia, the president of Malaysian Institute of Accountant (MIA), Abdul Rahim, has cited the need for an effective AC. Similar to the argument by Federal Committee on Corporate Governance (FCCG) (1999); highlighted the institute notes with concern that despite legislative support for the establishment of $\mathrm{AC}$, several listed companies are unable to develop independent $\mathrm{AC}$, and therefore, cannot discharge their responsibilities (Akhtaruddin \& Haron, 2010). In this study, this variable is measured by the ratio of independent non-executive members relative to the total members in the committee (Be'dard, Chtourou, \& Courteau, 2004). Based on the above argument, the forth proposed hypothesis is as follows:

H4: There is a positive relationship between audit committee independence and financial reporting disclosure quality.

\section{Audit committee size}

When more directors are added in the audit committee (AC), it ensures that more knowledge and skills act as resources for monitoring the disclosure quality (Yap \& Foo, 2012). In addition, potential issues regarding disclosure in corporate reporting are revealed because of higher number of members in the AC (Mohd Ghazali, 2014). Contrary to this Deumes and Knechel (2008) argued that the AC is an expensive monitoring mechanism and many companies are not willing to bear these expenses, especially those with high agency costs. Companies with fewer members in the AC, in average, devote less time to oversee the appointment of auditor, arguing with management and meeting with the people involved in internal controls.

Generally, the benefit of having many members in the AC may outweigh the exceeded cost required for communication and decision making which is linked with large AC (Beasley, Carcello, Hermanson, \& Neal, 2009). Large AC may become ineffective or less influential because of the fact that coordination and processes becomes complex (He, Labelle, Piot, \& Thornton, 2009). Therefore, Beasley, Carcello, Hermanson, and Neal (2009) highlighted the importance of optimal number of directors in the $\mathrm{AC}$, he further endorses that seven to eight members are enough.

In Malaysia, it was argued that the importance of expertise in the AC can be gained with the position of director in other companies (Ismail, Iskandar, and Rahmat, 2008). It has been suggested that the effectiveness of the AC is depending on the appropriate size of the AC (Felo, Krishnamurthy, \& Solieri, 2003; Rahman \& Ali, 2006). This study intends to examine the impact of audit size on the disclosure quality in Malaysia. This variable is measured by the total numbers of directors in the AC (Bhasin, 2013). Therefore, based on the above arguments the fifth proposed hypothesis is as follows:

$H_{5}$ : There is a relationship between audit committee size and financial reporting disclosure quality. 


\section{Audit committee expertise}

It has been argued that AC members need to have sufficient understanding of accounting and finance (i.e. have financial literacy) to perform effective monitoring for the integrity of company's FR process and its disclosure practices (Xie, Davidson, \& DaDalt, 2003). AC effectiveness is depending on the AC expertise. It improves their monitoring role for overseeing the disclosure quality (He, Labelle, Piot, \& Thornton, 2009). AC members typically have responsibility for oversight over FR process as well as corporate disclosures practices (Klein, 2002; Felo, Krishnamurthy, \& Solieri, 2003). Theoretically speaking, experience of AC in general and financial accounting expertise in particular, plays a vital role in mitigating agency costs. AC accounting experts provide such committee with an effective means of monitoring management's FR practices and reducing agency costs (Azmi, Samat, Zakaria, \& Yusof, 2013).

In Malaysia, Mohd Ghazali (2014) reported that AC with accounting or related financial management directors has no impact on audit report lag. Even though the FCCG (1999) noted that the public listed companies in Malaysia have successfully complied with the requirement of establishing an $\mathrm{AC}$, the quality of the members within such committee is questionable. The results of previous studies showed that $\mathrm{AC}$ expertise is an essential factor in promoting $\mathrm{AC}$ effectiveness as well as to provide disclosure quality of FR. The current study is concerning about audit committee expertise and measures it by the total number of members that have the experience and knowledge of financial audit and financial accounting (Cohen \& Krishnamoorthy, 2014). Therefore, based on the above discussion, the sixth proposed hypothesis is as follows:

H6: There is a positive relationship between audit committee expertise and financial reporting disclosure quality.

\section{External Auditor Characteristics}

Several researchers have argued that the brand name of auditor and the size of audit firms tend to have better strength of monitoring which enables the auditor to produce quality and credible information in the FR (Carcello \& Nagy, 2004; Cheng, Liao, \& Zhang, 2013). On the other hand, it has been observed that investors respond positively to the decision of the company regarding changing its auditor from large firm to small firm (Scarbrough, Rama, \& Raghunandan, 1998). Detection of material misstatement is dependent on the expertise of auditor, but the misstatement disclosure is the function of independence of auditor (Xie, Davidson, \& DaDalt, 2003). Level of independence varies across different audit firms. Small firms usually do not disclose material misstatements for retention of the client and relationship with the client (Spira, 1999). On the other hand, for large audit firms' reputation is more importance than retaining a client, so they cannot sacrifice independence and integrity. A hypothesis testing the relation between reputation and Big Four proved that previous clients of big audit firms involved in lesser earnings, whereas earnings are measured by cross sectional (Rahman \& Ali, 2006).

From the theoretical perspective, resource dependent theory proposed that AC with a resourcedependent focus evinced through industry expertise, experience, reputation, and networking of the members may positively enhance AC effectiveness (Cohen \& Krishnamoorthy, 2014). The efficient AC always chooses the quality auditors as Big Four. In this regard, first important point for Big Four who are good among external auditors, the reputation is the main concern for the large audit firms; these audit company characteristics enforce companies to avoid the coercive decisions (Penman, 2007). Second the large audit firm has more resources compare to small firm such as the financial resource to invest in the technology and training to their staff for the efficiency (SMSF Adviser, 2014). Third litigation risk and lawsuits expectancy also have been the factors that provide higher quality of audit from the large audit firms. 
The foremost important aspect which cannot be ignored is Big Four; if the audit is being conducted by the big firms then it is considered that financial reports have been developed in accordance with the international standards and show the true and fair view of the company (DeAngelo, 1981; Carcello \& Nagy, 2004; Ismail, Iskandar, \& Rahmat, 2008). This variable is a dummy variable and measured by " 1 " if company is audited by "big 4 " or " 0 " otherwise (Rahman \& Ali, 2006). These big four companies are; PricewaterhouseCoopers (PwC), Deloitte, Ernst \& Young (EY) and KPMG. Therefore, the seventh proposed hypothesis is formulated as follows:

$H_{7}$ : There is a positive relationship between external auditor and financial reporting disclosure quality.

\section{Research Methodology}

In order to meet the overall research question, this study adopted a quantitative research methodology. A sample of Top150 firms (by market capitalization) listed on the Main market of Bursa Malaysia for the year 2014 was selected. This year is selected because staring from 2014, the economy in Malaysia was fluctuating due to currency depreciation by more than $17.5 \%$ by the end of 2014 which is negatively affecting the investment in companies in Malaysia. Secondary sources are used to collect the data for this research. Mainly the annual reports of the companies have been viewed. In the annual report, data related to the directors' report, directors' profile, CEO report, statement of CG, statement of directors' shareholdings, the financial statements, and notes to the accounts were scrutinized. Board characteristics, AC characteristics, and external auditor represented by the big four have been taken as independent variables. In this study, disclosure quality of financial reporting is measured by A disclosure index of 12 items on the basis of (Abdullah, Evans, Fraser, \& Tsalavoutas, 2015) is used in this study in order to measure the extent of disclosure quality, particularly in companies' annual reports. An un-weighted approach is applied, whereby a company is awarded 3 if all items that should be disclosed have been disclosed ( 12 items), 2 if more than 8 (out of 12 items) are disclosed, and 1 if only 8 items or less have not been disclosed. Thus, after assigning values the sum was calculated and then if the sum was less than 8 then 1 was assigned if more than 8 then 2 and if any company was following all of the 12 standards than 3 were assigned to that company (Abdullah, Evans, Fraser, \& Tsalavoutas, 2015). According to Abdullah, Evans, Fraser and Tsalavoutas (2015) the eight standards are most important in showing transparency in the financial statements, and twelve standards show enough disclosure which ensures quality of financial statements. If any company is not showing the minimum of eight standards which are prescribed above, it means that the company is not disclosing their actual issues (See Table IV).

The literature has shown that firm size influences the reporting quality. This is because the big companies have a big audit committee as they have more resources to afford such costs for the improvement of FR. Big companies are supposed to prepare quality reports as they are more visible to the investor and require outside capital (Craven \& Marston, 1999). Therefore, it is expected that disclosure quality, board characteristics, AC characteristics, and Big Four may be positively associated with firm size. In short, to test the hypotheses, all data will be analyzed using the SPSS version 20.0, a multiple regression analysis is utilized to analyze the data for this study and this method is in tandem with the previous studies (e.g. Camfferman and Cooke, 2002; Gul and Leung, 2004; Laswad et al., 2005; Al_arussi et al., 2011). In short, the proposed equation is as follows: 
FRDQ

$$
\begin{aligned}
= & a+\beta 1 \mathrm{BC}+\beta 2 \mathrm{BS}+\beta 3 \mathrm{BE}+\beta 4 \mathrm{ACI}+\beta 5 \mathrm{ACS}+\beta 6 \mathrm{ACE} \beta 7 \mathrm{BF}+\beta 8 \\
& \mathrm{FS}+\varepsilon
\end{aligned}
$$

Which:

$\begin{array}{ll}\text { FRDQ } & \text { Financial Reporting Disclosure Quality } \\ \text { BC } & \text { Board Composition } \\ \text { BS } & \text { Board Size } \\ \text { BE } & \text { Board Expertise } \\ \text { ACI } & \text { Audit Committee Independence } \\ \text { ACS } & \text { Audit Committee Size } \\ \text { ACE } & \text { Audit Committee Expertise } \\ \text { BF } & \text { Big Four } \\ \text { FS } & \text { Firm size } \\ \alpha 0 & \text { constant } \\ \varepsilon & \text { error term }\end{array}$

\section{Data Analysis}

\section{Descriptive Statistics}

The first analyzing of data is the descriptive analysis which mostly represents frequency distributions, in other words, it represents the frequency of incidence of each score value. For checking the normality of the data, another important measure that is commonly used in Skewness and kurtosis. The acceptable threshold statistical values (Z) for Skewness is less than three and for Kurtosis the value should be less than eight (Hair, Black, Babin \& Anderson, 2010). Based on the values of Skewness and kurtosis for all the variables in Table I, the variable seems to be normal for further analysis.

Table I Skewness and Kurtosis

\begin{tabular}{lccc}
\hline & & & \\
& $\mathrm{N}$ & Skewness & Kurtosis \\
& Statistic & Statistic & Statistic \\
\hline Financial Reporting Disclosure Quality & 150 & -0.010 & -0.993 \\
Board Composition & 150 & 0.786 & 0.486 \\
Board Size & 150 & 0.564 & 0.151 \\
Board Experience & 150 & 0.795 & 0.845 \\
Audit Committee Independence & 150 & -0.560 & -0.575 \\
Audit Committee Size & 150 & 1.634 & 2.279 \\
Audit Committee Experience & 150 & 0.402 & 0.466 \\
Large Audit Firms & 150 & -1.414 & -0.002 \\
Firm Size & 150 & 1.214 & 2.645 \\
\hline
\end{tabular}

All the values calculated above are in the threshold levels. Thus, there is no harm in saying that the data is quite normal and is ready for further analysis. For further screening and checking the normality of the data diagnostic tests for checking the issue of multicollinearity have been applied. In addition, if the outcome of the multicollinearity is high then one of the variables has to be deleted (Hair, Black, Babin, \& Anderson, 2010). A popular method of multicollinearity detection and measurement utilizes VIF and tolerance to determine the influence of a study's independent variable (Mansfield \& Helms, 1982). The acceptable threshold level refers to tolerance value greater than 0.10 and VIF value less than 10 (Cornell, 1987; Silver, 1997). According to the table II, it is discovered that all correlation between independent variables are less than 10 . 
Table II Tolerance and Variable Inflation Factor

\begin{tabular}{llcc}
\hline & & \multicolumn{2}{c}{ Collinearity Statistics } \\
\cline { 3 - 4 } Model & & Tolerance & VIF \\
\hline 1 & (Constant) & 0.691 & 1.447 \\
& Board Composition & 0.622 & 1.607 \\
& Board Size & 0.710 & 1.408 \\
& Board experience & 0.733 & 1.364 \\
& Audit Committee Independence & 0.648 & 1.542 \\
& Audit Committee Size & 0.706 & 1.417 \\
& Audit committee experience & 0.825 & 1.081 \\
& Large Audit Firms & 0.882 & 1.134 \\
& Firm Size & & \\
\hline
\end{tabular}

Correlation Analysis

Correlation analysis is used to examine the degree of mutual linear association among variables involved in the analysis (Hair, Black, Babin, \& Anderson, 2010). The value of the correlation coefficient lies between minus one and plus one. Table III discloses the values of the coefficient of correlation among board characteristics, AC characteristics, external auditor, and FR disclosure quality. If the value of correlation coefficient exceeds 0.90 among the variables, it indicates the occurrence of multicollinearity (Mansfield \& Helms, 1982).

Table III Cross Correlations

\begin{tabular}{|c|c|c|c|c|c|c|c|c|c|}
\hline Variables & FRQ & $\mathrm{BC}$ & BS & $\mathrm{BE}$ & $\mathrm{ACI}$ & $\mathrm{ACS}$ & $\mathrm{ACE}$ & LAF & $\mathrm{FS}$ \\
\hline FRQ & 1 & & & & & & & & \\
\hline $\mathrm{BC}$ & -.003 & 1 & & & & & & & \\
\hline BS & $.485^{* *}$ & $-.204^{*}$ & 1 & & & & & & \\
\hline $\mathrm{BE}$ & $.279^{* *}$ & .030 & -.153 & 1 & & & & & \\
\hline ACI & $.246^{* *}$ & $.335^{* *}$ & .026 & .130 & 1 & & & & \\
\hline $\mathrm{ACS}$ & $.322^{* *}$ & $.167^{*}$ & $.402^{* *}$ & .055 & -.152 & 1 & & & \\
\hline $\mathrm{ACE}$ & $.185^{*}$ & -.078 & -.141 & $.465^{* *}$ & .149 & $-.213^{* *}$ & 1 & & \\
\hline LAF & $.268^{* *}$ & -.003 & $.210^{*}$ & .034 & .086 & .109 & -.092 & 1 & \\
\hline $\mathrm{FS}$ & $.791^{*}$ & .076 & $.245^{* *}$ & -.029 & -.100 & $.166^{*}$ & -.131 & .143 & 1 \\
\hline
\end{tabular}

*. Correlation is significant at the 0.05 level (2-tailed)

Majority of these values of coefficient of correlations have relationships but these relationships are not that much strong where one variable need to be deleted. Some of the correlations are significant at $0.05 \%$ level of significance (Rodgers \& Nicewander, 1988) where few are significant at $0.01 \%$ level of significance (Rodgers \& Nicewander, 1988), however, few correlations are insignificant.

\section{Results and discussion}

Assumptions of multiple regressions, i.e. normality and multicollinearity have already been analyzed which shows that the data is suitable for analysis. After having the surety that the data is suitable for analysis the multiple regression analysis was conducted. Table V shows the outcomes that are measured by $\mathrm{R}^{2}$ and this denotes the effect of independent variables over the dependent variable. According to the $\mathrm{R}^{2}$ of $45.5 \%$, it can be ensured that above $40 \%$ of the relationship with FR disclosure quality can be determined by the seven independent variables while the remaining impact over disclosure quality is determined by other factors. To further strengthen the analysis, the value of Durbin Watson has been calculated. The threshold level for Durbin Watson is that the value should be in between 1.5 to 2.5; these ranges suggested absence of autocorrelation (Fomby \& Guilkey, 1978). Calculated value of Durbin Watson is 2.114 which show that the model is acceptable (Hill \& Flack, 1987). 
Table V Coefficients

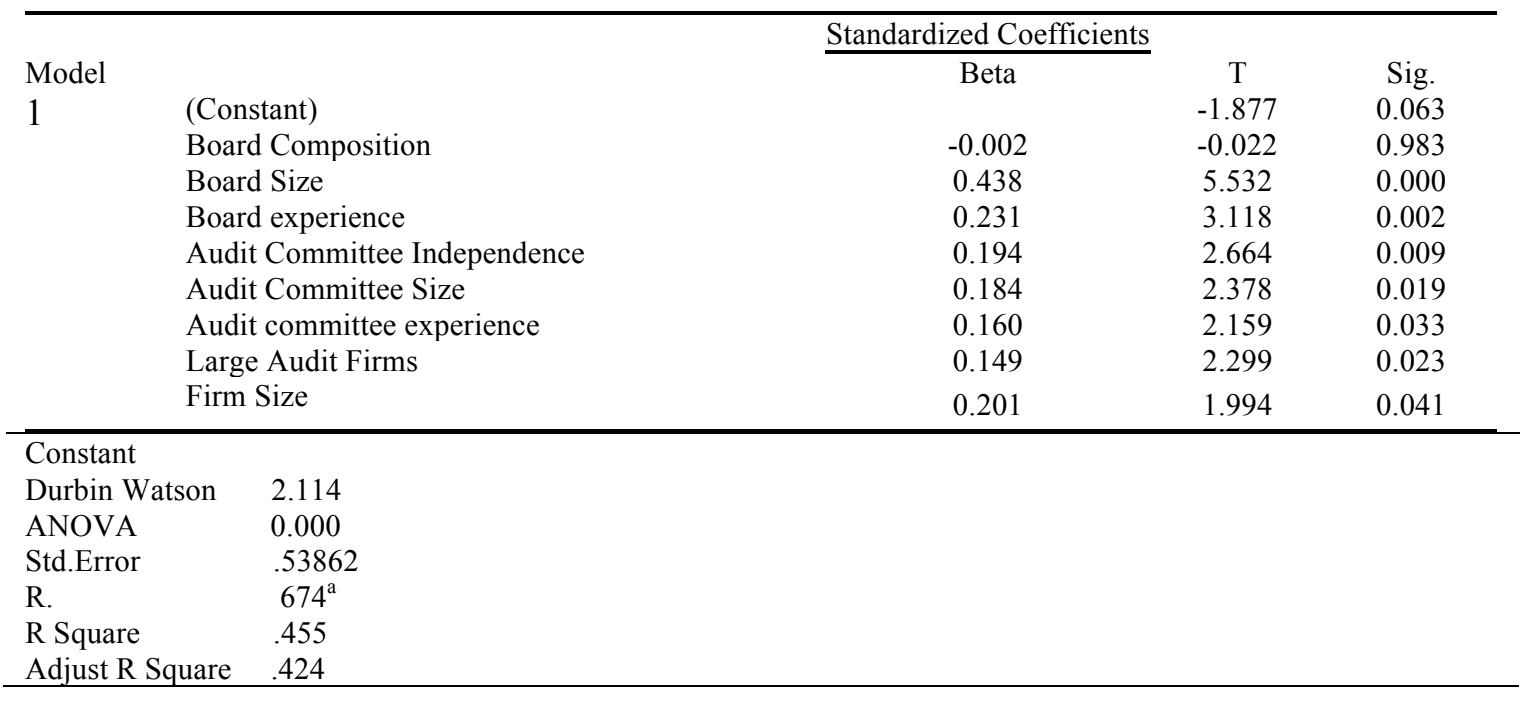

The following section explains the results of the regression analysis regarding the proposed hypotheses.

\section{Board composition}

Based on Table V, FR disclosure quality is not influenced by board composition as it has shown an insignificant negative relationship as depicted by the beta value which is -0.002 and $t$ value which is -0.022 . Therefore, the first hypothesis is rejected. The findings are consistent with Bhagat and Bolton (2008). The basic reason behind this insignificant relation is that higher ratio of independent directors in the board appears to worsen audit lag (Dehaan, Hodge, \& Shevlin, 2013).

\section{Board size}

Table V shows that FR disclosure quality is influenced by board size as it has a significant positive relationship as shown by beta value of 0.438 and $t$ value of 5.532. The results of the study are in association with the findings conducted by Cohen, Krishnamoorthy and Wright (2004) and Al_arussi et al., (2009). In the case of Malaysia, it appears that more No of expertise members in the board help company to enhance its disclosure quality of financial reporting. Therefore, the second hypothesis is accepted.

\section{Board expertise}

Based on the finding in Table V, FR quality is influenced by board expertise and has a significant positive relationship as shown by beta value $\beta$ i.e. 0.231 and $t$ value i.e. 3.118. The findings are in support of studies conducted by Be'dard, Chtourou and Courteau (2004). This result highlights the importance of qualification and experience in the function of board of directors. Therefore, the third hypothesis is accepted.

\section{Audit Committee independence}

Table $\mathrm{V}$ shows that FR disclosure quality is influenced by AC independence as it has a significant positive relationship with FR quality because the beta value is 0.194 and $t$ value is 2.664. The findings of the study are in accordance with the findings of Be'dard, Chtourou and Courteau (2004). Therefore, it is clear that more independent directors enhance the independency of $\mathrm{AC}$ and ultimately improve the disclosure quality of financial statements 
(García Lara, García Osma, \& Penalva, 2014; Chen, Hope, Li, \& Wang, 2015). In short, the forth hypothesis is accepted.

\section{Audit Committee Size}

Based on Table V this study endorsed that FR disclosure quality is influenced by AC size and it has a significant positive relationship with FR disclosure quality, the beta value of the variable is 0.184 and $t$ value is 2.378 . The results of the study are in consistent with Felo, Krishnamurthy and Solieri (2003). The results confirm that the effectiveness of the AC is depending on the appropriate size of the AC (Felo, Krishnamurthy, \& Solieri, 2003; Rahman \& Ali, 2006), therefore, the fifth hypothesis is accepted.

\section{Audit Committee experience}

Based on Table V this study has an opinion that FR disclosure quality is influenced by AC experience and has a significant positive relationship with disclosure quality as shown by the beta value of 0.160 and $t$ value of 2.159. The findings are consistent with Be'dard, Chtourou and Courteau (2004) as AC expertise is an essential factor in promoting AC effectiveness and enhancing disclosure quality of FR. Hence, the sixth hypothesis is accepted.

\section{Big Audit Firm}

Based on Table $\mathrm{V}$ this study has an opinion that disclosure quality is influenced by large audit firm and has a significant relationship with FR disclosure quality as shown by the beta value of 0.149 and $t$ value of 2.299. The findings are consistent with the results of DeAngelo (1981) and AL_arussi et al., (2009). So, based on these results, if the audit is being conducted by the big firms then it is considered that financial reports have been developed in accordance with the international standards and show the true and fair view of the company (DeAngelo, 1981; Carcello \& Nagy, 2004; Ismail, Iskandar, \& Rahmat, 2008), in other words, the disclosure quality of Financial reporting will be high. Therefore, the seventh hypothesis is accepted.

For control variable (firm size), it has been observed that it is showing a positive and significant relationship, as the big companies are under the public eye and observations, and this clearly shows a significant positive controlling effect over the disclosure quality.

\section{Conclusion and Implications of study}

This study examines the factors that may influence FR disclosure quality. The study focuses on board characteristics, audit committee characteristics, and external audit to ensure disclosure quality. The study has taken a sample of 150 non-financial listed companies of Bursa Malaysia. The regression analysis is applied to examine the association between independent variables and dependent variable. The findings of the research show that board characteristics, audit committee characteristics and Big Fours have a significant positive impact over disclosure quality of financial reporting. The results of this study surely provide numerous insights that may be of great interests for the scholars, government, shareholders, and policy makers. This study has theoretical and practical implications as it is supported by two theories and further expands the horizon of agency theory and resource dependency theory. For practitioners, the study provided the most influential and common factors that may enhance the disclosure quality of financial reporting.

\section{Limitation and Future Research}

Along with different contributions of this study, there are several limitations attached with it. The present study tested the effect of few selected factors on disclosure quality. Likewise, the measurement of FR quality has been made on only one method. Furthermore, the study does 
not focus on any specific industry and chose 150 companies from different sectors. Another limitation is that the research focused only on non-financial firms and excluded other financial institutions. The study used cross-sectional data; all the values were extracted from the financial statements of the financial years 2014 only due to the time and cost limitations.

Future studies may apply the same model in different geographical portions to see the difference with FR disclosure quality. Therefore, it is suggested that same methodology can be used by future studies for other countries where this relationship has not yet been tested. The basic reason behind this suggestion is that countries differ in environment, cultures, education, policies, legal systems etc.

Table IV Dependent variable Measurements

\begin{tabular}{|c|c|c|c|}
\hline No. & Standards & Name of reporting Standard & Measurement \\
\hline 1 & MFRS2 & Share Based Payment & $\begin{array}{l}\text { Equal ' } 1 \text { ' if the company follows } \\
\text { this standard and ' } 0 \text { ' otherwise. }\end{array}$ \\
\hline 2 & MFRS3 & Business Combinations & $\begin{array}{l}\text { Equal ' } 1 \text { ' if the company follow this } \\
\text { standard and ' } 0 \text { ' otherwise }\end{array}$ \\
\hline 3 & MFRS 5 & $\begin{array}{c}\text { Non-current Assets held for Sale and } \\
\text { Discontinued Operations }\end{array}$ & $\begin{array}{l}\text { Equal ' } 1 \text { ' if the company follow this } \\
\text { standard and '0' otherwise }\end{array}$ \\
\hline 4 & MFRS 117 & Leases & $\begin{array}{l}\text { Equal ' } 1 \text { ' if the company follow this } \\
\text { standard and ' } 0 \text { ' otherwise }\end{array}$ \\
\hline 5 & MFRS 132 & $\begin{array}{c}\text { Financial Instruments: Disclosure and } \\
\text { Presentation }\end{array}$ & $\begin{array}{l}\text { Equal ' } 1 \text { ' if the company follow this } \\
\text { standard and '0' otherwise }\end{array}$ \\
\hline 6 & MFRS 136 & Impairment of Assets & $\begin{array}{l}\text { Equal ' } 1 \text { ' if the company follow this } \\
\text { standard and ' } 0 \text { ' otherwise }\end{array}$ \\
\hline 7 & MFRS 138 & Intangible Assets & $\begin{array}{l}\text { Equal ' } 1 \text { ' if the company follow this } \\
\text { standard and ' } 0 \text { ' otherwise }\end{array}$ \\
\hline 8 & MFRS 140 & Investment Property & $\begin{array}{l}\text { Equal ' } 1 \text { ' if the company follow this } \\
\text { standard and ' } 0 \text { ' otherwise }\end{array}$ \\
\hline 9 & MFRS 101 & Presentation of Financial Statements & $\begin{array}{l}\text { Equal ' } 1 \text { ' if the company follow this } \\
\text { standard and ' } 0 \text { ' otherwise }\end{array}$ \\
\hline 10 & MFRS 114 & Segmental Reporting & $\begin{array}{l}\text { Equal ' } 1 \text { ' if the company follow this } \\
\text { standard and ' } 0 \text { ' otherwise }\end{array}$ \\
\hline 11 & MFRS 116 & Property, Plant and Equipment & $\begin{array}{l}\text { Equal ' } 1 \text { ' if the company follow this } \\
\text { standard and '0' otherwise }\end{array}$ \\
\hline 12 & MFRS 119 & Employee Benefits & $\begin{array}{l}\text { Equal ' } 1 \text { ' if the company follow this } \\
\text { standard and ' } 0 \text { ' otherwise }\end{array}$ \\
\hline
\end{tabular}




\section{References}

Abbott, L. J., Daugherty, B., Parker, S., \& Peters, G. F. (2015). Internal audit quality and financial reporting quality: The joint importance of independence and competence. Journal of Accounting Research, 54(1), 3-40.

Abdullah, M., Evans, L., Fraser, I., \& Tsalavoutas, I. (2015). IFRS Mandatory disclosures in Malaysia: the influence of family control and the value (ir)relevance of compliance levels. Accounting Forum, 1-21.

Akhtaruddin, M., \& Haron, H. (2010). Board ownership, audit committees' effectiveness and corporate voluntary disclosures. Asian Review of Accounting, 18(1), 68-82. doi:10.1108/13217341011046015

Al_arussi, A.S., MH Selamat, M Mohd Hanefah, (2009), Determinants of financial and environmental disclosures through the internet by Malaysian companies, Asian Review of Accounting 17 (1), 59-76.

Al_arussi, A.S., MH Selamat, M Mohd Hanefah, (2011), The determinants of internet financial disclosure: The perspective of Malaysian listed companies, International Journal of Management Studies (IJMS) 18 (1), 1-29.

Albring, S. M., Huang, S. X., Pereira, R., \& Xu, X. (2013). The effects of accounting restatements on firm growth. Journal of Accounting and Public Policy, 33(2), 357-376.

Allegrini, M., \& Greco, G. (2013). Corporate boards, audit committees and voluntary disclosure: Evidence from Italian listed companies. Journal of Management \& Governance, 17(1), 187216.

Alzoubi, E. S. (2012). Board characteristics and financial reporting quality among Jordanian listed companies: Proposing conceptual framework. Asian Journal of Finance $\mathcal{E}$ Accounting, 4(1), 245-258.

Armstrong, C. S., Guay, W. R., \& Weber, J. P. (2010). The role of information and financial reporting in corporate governance and debt contracting. Journal of Accounting and Economics, 50(3), 179-234. doi:10.1016/j.jacceco.2010.10.001

Azmi, N. A., Samat, O., Zakaria, N. B., \& Yusof, M. M. (2013). Audit committee attributes on audit fees: The impact of Malaysian code of corporate governance (MCCG) 2007. Journal of Modern Accounting and Auditing, 9(11), 1442-1453.

Bainbridge, S. M. (2013). Preserving director primacy by managing shareholder interventions. Research Handbook on Shareholder Power and Activism, Forthcoming, 13-09.

Balakrishnan, K., Billings, M. B., Kelly, B., \& Ljungqvist, A. (2014). Shaping liquidity: On the causal effects of voluntary disclosure. The Journal of Finance, 69(5), 2237-2278.

Ball, R. (2006). International Financial Reporting Standards (IFRS): Pros and cons for investors. Accounting and Business Research, 36(1), 5-27. doi:10.1080/00014788.2006.9730040

Bansal, N., \& Sharma, A. K. (2016). Audit committee, corporate governance and firm performance: Empirical evidence from India. International Journal of Economics and Finance, 8(3). doi:10.5539/ijef.v8n3p103

Be'dard, J., Chtourou, S. M., \& Courteau, L. (2004). The effect of audit committee expertise, independence, and activity on aggressive earnings management. Auditing: A Journal of Practice \& Theory, 23(2), 13-35.

Beasley, M. S. (1996). An empirical analysis of the relation between the board of director composition and financial statement fraud. The Accounting Review, 71(4), 443-465.

Beasley, M. S., Carcello, J. V., Hermanson, D. R., \& Neal, T. L. (2009). The Audit Committee Oversight Process. Contemporary Accounting Research, 26(1), 65-122. 
Bertoni, F., Ferrer, M. A., \& Martí, J. (2013). The different roles played by venture capital and private equity investors on the investment activity of their portfolio firms. Small Business Economics, 40(3), 607-633.

Bhagat, S., \& Bolton, B. (2008). Corporate governance and firm performance. Journal of Corporate Finance, 14, 257-273.

Bhasin, M. (2013). Audit Committee Scenario \& Trends: Evidence from an Asian Country. . European Journal of Business and Social Sciences,, 1(11), 1-23.

Brandes, P., Dharwadkar, R., \& Suh, S. (2015). I know something you don't know!: The role of linking pin directors in monitoring and incentive alignment. Strategic Management Journal.

Byard, D., Li, Y., \& Weintrop, J. (2006). Corporate governance and the quality of financial analysts' information. Journal of Accounting and Public Policy, 25(5), 609-625. doi:10.1016/j.jaccpubpol.2006.07.003

Cadbury, A. (1992). The Financial Aspects of Corporate Governance. London: Burgess Science Press.

Carcello, J. V., \& Nagy, A. L. (2004). Client size, auditor specialization and fraudulent financial reporting. Managerial Auditing Journal, 19(5), 651-668. doi:org/10.1108/02686900410537775

Carcello, J. V., Hermanson, D. R., \& Ye, Z. (2011). Corporate governance research in accounting and auditing: Insights, practice implications, and future research directions. Auditing: $A$ Journal of Practice \& Theory, 30(3), 1-31.

Chen, F., Hope, O. K., Li, Q., \& Wang, X. (2015). Flight to Quality in International Markets: Political Uncertainty and Investors' Demand for Financial Reporting Quality. Demand for Financial Reporting Quality.

Chen, X., Cheng, Q., \& Wang, X. (2015). Does increased board independence reduce earnings management? Evidence from recent regulatory reforms. Review of Accounting Studies, 20(2), 899-933.

Cheng, L., Liao, S., \& Zhang, H. (2013). The commitment effect versus information effect of disclosure-evidence from smaller reporting companies. The Accounting Review, 88(4), 1239-1263.

Cheng, S. (2008). Board size and the variability of corporate performance. Journal of Financial Economics, 87(1), 157-176. doi:10.1016/j.jfineco.2006.10.006

Cohen, J. R., \& Krishnamoorthy, G. W. (2014). The effect of audit committee industry expertise on monitoring the financial reporting process. The Accounting Review, 89(1), 243-273. doi:http://dx.doi.org/10.2308/accr-50585

Cohen, J. R., Krishnamoorthy, G., \& Wright, A. (2004). The corporate governance mosaic and financial reporting quality. Journal of Accounting Literature, 87-152.

Cormier, D., Magnan, M., \& Velthoven, B. V. (2005). Environmental disclosure quality in large German companies: Economic incentives, public pressures or institutional conditions? European Accounting Review, 14(1), 3-39. doi:10.1080/0963818042000339617

Cornell, J. A. (1987). Classical and modern regression with applications. Technometrics, 29(3), 377-378.

Craven, B. M., \& Marston, C. L. (1999). Financial reporting on the Internet by leading UK companies. European Accounting Review, 8(2), 321-333. doi:10.1080/096381899336069

Daske, H., \& Gebhardt, G. (2006). International financial reporting standards and experts' perceptions of disclosure quality. A Journal of Accounting Finance and Business Studies, 42(3), 461-498. doi:10.1111/j.1467-6281.2006.00211.x

DeAngelo, L. E. (1981). Auditor size and audit quality. Journal of Accounting and Economics, 3(3), 183-199. doi:10.1016/0165-4101(81)90002-1 
Dehaan, E., Hodge, F., \& Shevlin, T. (2013). Does voluntary adoption of a clawback provision improve financial reporting quality? Contemporary Accounting Research, 30(3), 1027-1062.

Deumes, R., \& Knechel, W. R. (2008). Economic incentives for voluntary reporting on internal risk management and control systems. Auditing: A Journal of Practice $\&$ Theory, 27(2), 3566.

Eisenberg, T., Sundgren, S., \& Wells, M. T. (1998). Larger board size and decreasing firm value in small firms. Journal of Financial Economics, 48(1), 35-54. doi:10.1016/S0304405X(98)00003-8

Eisenhardt, K. M. (1989). Agency theory: An assessment and review. Academy of Management Review, 14(1), 57-74.

Felo, A. J., Krishnamurthy, S., \& Solieri, S. A. (2003). Audit committee characteristics and the perceived quality of financial reporting: An empirical analysis. Social Science Research Network, 1-40.

Fernando, A. C. (2009). Corporate governance: Principles, policies, and practices. New Dehli: Pearson Education India.

Fifka, M. S. (2013). Corporate Responsibility Reporting and its Determinants in Comparative Perspective-A Review of the Empirical Literature and a Meta-analysis. Business strategy and the environment, 22(1), 1-35.

Firth, M., Wong, S., Xin, Q., \& Yick, H. Y. (2014). Regulatory sanctions on independent directors and their consequences to the director labor market: Evidence from China. Journal of Business Ethics, 1-16.

Fomby, T. B., \& Guilkey, D. K. (1978). On choosing the optimal level of significance for the Durbin-Watson test and the Bayesian alternative. Journal of Econometrics, 8(2), 203-213. doi:10.1016/0304-4076(78)90029-5

Frias-Aceituno, J. V., Rodríguez-Ariza, L., \& Garcia-Sánchez, I. M. (2014). Explanatory factors of integrated sustainability and financial reporting. Business Strategy and the Environment, $23(1), 56-72$.

García Lara, J. M., García Osma, B., \& Penalva, F. (2014). Information consequences of accounting conservatism. European Accounting Review, 23(2), 173-198.

Gigler, F., Kanodia, C., Sapra, H., \& Venugopalan, R. (2014). How frequent financial reporting can cause managerial short-termism: An analysis of the costs and benefits of increasing reporting frequency. Journal of Accounting Research, 52(2), 357-387.

Goodman, T. H., Neamtiu, M., Shroff, N., \& White, H. D. (2013). Management forecast quality and capital investment decisions. The Accounting Review, 89(1), 331-365.

Graham, J. R., Harvey, C. R., \& Rajgopal, S. (2005). The economic implications of corporate financial reporting. Journal of Accounting and Economics, 40(1), 3-73. doi:10.1016/j.jacceco.2005.01.002

Hair, J. F., Black, B., Babin, B., \& Anderson, R. E. (2010). Multivariate Data Analysis. IVew Jersey: Pearson Education International.

Hambrick, D. C., Misangyi, V. F., \& Park, C. A. (2015). The quad model for identifying a corporate director's potential for effective monitoring: Toward a new theory of board sufficiency. Academy of Management Review, 40(3), 323-344.

Hashim, H. A., \& Devi, S. (2008). Board characteristics, ownwership Structure and earnings quality: Malaysian evidence. Research in Accounting and Emerging Economies, 8(1), 97-123. doi:10.1016/S1479-3563(08)08004-3

He, L., Labelle, R., Piot, C., \& Thornton, D. B. (2009). Board monitoring, audit committee effectiveness, and financial reporting quality: Review and synthesis of empirical evidence. Journal of Forensic \& Investigative Accounting, 2(1), 32-45. 
Hill, C. W., \& Jones, T. M. (1992). Stakeholder-agency theory. Journal of Management Studies, 29(2), 131-154.

Hill, R. J., \& Flack, H. D. (1987). The use of the Durbin-Watson d statistic in Rietveld analysis. Journal of Applied Crystallography, 20, 365-361. doi:10.1107/S0021889887086485

Hillman, A. J., \& Dalziel, T. (2003). Boards of directors and firm performance: Integrating agency and resource dependence perspectives. Academy of Management review,, 28(1), 383-396.

Hutchinson, M., Mack, J., \& Plastow, K. (2015). Who selects the 'right'directors? An examination of the association between board selection, gender diversity and outcomes. Accounting E Finance, 55(4), 1071-1103.

Ismail, H., Iskandar, T. M., \& Rahmat, M. M. (2008). Corporate reporting quality, audit committee and quality of audit. Malaysian Accounting Review, 7(1), 21-42.

Ismail, N. A., \& King, M. (2014). Factors influencing the alignment of accounting information systems in small and medium sized Malaysian manufacturing firms. Journal of Information Systems and Small Business, 2(1), 1-20.

Jennings, M. M. (2003). Primer on Enron: Lessons from a perfect storm of financial reporting, corporate governance and ethical culture failures. California Westren Law Review, 39(2).

Jiang, H., Habib, A., \& Hu, B. (2011). Ownership concentration, voluntary disclosures and information asymmetry in New Zealand. The British Accounting Review, 43(1), 39-53. doi:10.1016/j.bar.2010.10.005

Johl, S., Kaur Johl, S., Subramaniam, N., \& Cooper, B. (2013). Internal audit function, board quality and financial reporting quality: Evidence from Malaysia. Managerial Auditing Journal, 28(9), 780-814.

Kirkpatrick, G. (2009). The corporate governance lessons from the financial crisis. Financial Market Trends, 3(1), 61-87. doi:10.1787/fmt-v2009-art3-en

Klein, A. (2002). Audit committee, board of director characteristics, and earnings management. Journal of Accounting and Economics, 33(3), 375-400. doi:10.1016/S0165-4101(02)00059-9

Li, J., Mangena, M., \& Pike, R. (2012). The effect of audit committee characteristics on intellectual capital disclosure. The British Accounting Review, 44(2), 98-110.

Low, D. C., Roberts, H., \& Whiting, R. H. (2015). Board gender diversity and firm performance: Empirical evidence from Hong Kong, South Korea, Malaysia, and Singapore. PacificBasin Finance Journal, 381-401.

Mansfield, E. R., \& Helms, B. P. (1982). Detecting multicollinearity. The American Statistician, 36(3), 158-160. doi:10.1080/00031305.1982.10482818

Martínez-Ferrero, J., Garcia-Sanchez, I. M., \& Cuadrado-Ballesteros, B. (2015). Effect of financial reporting quality on sustainability information disclosure. Corporate Social Responsibility and Environmental Management, 22(1), 45-64.

McDonald, M. L., \& Westphal, J. D. (2013). Access denied: Low mentoring of women and minority first-time directors and its negative effects on appointments to additional boards. Academy of Management Journal, 56(4), 1169-1198.

Mio, C., \& Venturelli, A. (2013). Non-financial Information About Sustainable Development and Environmental Policy in the Annual Reports of Listed Companies: Evidence from Italy and the UK. Corporate Social Responsibility and Environmental Management, 20(6), 340-354.

Mohd Ghazali, N. A. (2014). Board of directors and performance of Malaysian companies. International Journal of Managerial and Financial Accounting, 6(2), 117-132.

Nyazeva, A., Knyazeva, D., \& Masulis, R. W. (2013). The supply of corporate directors and board independence. Review of Financial Studies, 26(6), 1561-1605. 
O'Connor, J. P., Priem, R. L., Coombs, J. E., \& Gilley, K. M. (2006). Do CEO stock options prevent or promote fraudulent financial reporting? Academy of Management Journal, 49(3), 483-500. doi:10.5465/AMJ.2006.21794666

Penman, S. H. (2007). Financial reporting quality: Is fair value a plus or a minus? Accounting and Business Research, 37(1), 33-44. doi:10.1080/00014788.2007.9730083

PricewaterhouseCoopers. (2011). Audit Committee Effectiveness: What Works Best.

Rahman, R. A., \& Ali, F. H. (2006). Board, audit committee, culture and earnings management: Malaysian evidence. Managerial Auditing Journal, 21(7), 783-804. doi:10.1108/02686900610680549

Rodgers, J. L., \& Nicewander, W. A. (1988). Thirteen ways to look at the correlation coefficient. The American Statistician', 42(1), 59-66. doi:10.1080/00031305.1988.10475524

Ruigrok, W., Peck, S., \& Tacheva, S. (2007). Nationality and gender diversity on Swiss corporate boards. Corporate Governance: An International Review, 15(4), 546-557. doi:10.1111/j.14678683.2007.00587.x

Scarbrough, D. P., Rama, D. V., \& Raghunandan, K. (1998). Audit committee composition and interaction with internal auditing: Canadian evidence. Accounting Horizons, 12(1), 51-62.

Shukeri, S. N., Shin, O. W., \& Shaari, M. S. (2012). Does board of director's characteristics affect firm performance? Evidence from Malaysian public listed companies. International Business Research, 5(9), 1-120.

Silver, E. A. (1997). Fostering creativity through instruction rich in mathematical problem solving and problem posing. ZDM, 29(3), 75-80. doi:10.1007/s11858-997-0003-x

Singhvi, S. S., \& Desai, H. B. (1971). An empirical analysis of the quality of corporate financial disclosure. The Accounting Review, 46(1), 129-138.

SMSF Adviser. (2014, September 4). Auditors under the spotlight. Retrieved from SMSF Advisers: http://www.smsfadviseronline.com.au/columns/item/241-auditors-under-the-spotlight

Spira, L. F. (1999). Independence in corporate governance: The audit committee role. Business Ethics A European Review, 8(4), 262-273.

Srinivasan, S. (2005). Consequences of financial reporting failure for outside directors: Evidence from accounting restatements and audit committee members. Journal of Accounting Research, 43(2), 291-334. doi:10.1111/j.1475-679x.2005.00172.x

Tong, C. K. (2014). Centripetal authority, differentiated networks: The social organization of Chinese firms in Singapore. chinese business Springer Singapore, 21-40.

Wind, M. A. (2012, January 8). Mulpha International reprimanded. Retrieved from Aisa Sentinel: http://www.asiasentinel.com/blog/mulpha-international-reprimanded/

Xie, B., Davidson, W. N., \& DaDalt, P. J. (2003). Earnings management and corporate governance: the role of the board and the audit committee. Journal of Corporate Finance, 9(3), 295-316. doi:10.1016/S0929-1199(02)00006-8

Yap, A., \& Foo, B. (2012, January 6). Sabotage. Retrieved from Selangor Times: http://www.scribd.com/doc/77339443/Selangor-Times-2012-Jan-6\#scribd

Yoshikawa, T., Zhu, H., \& Wang, P. (2014). National governance system, corporate ownership, and roles of outside directors: A corporate governance bundle perspective. Corporate Governance: An International Review, 22(3), 252-265.

Zahiruddin, G., \& Manab, N. A. (2013). The Effect of Malaysian Code of Corporate Governance (MCCG) Implementation to Companies' Performances. Journal of Accounting, Finance and Economics, 3, 43-52.

Zikmund, W. G. (2006). Business Research Methods. New York: McGrawHill.

Zona, F., Zattoni, A., \& Minichilli, A. (2013). A contingency model of boards of directors and firm innovation: The moderating role of firm size. British Journal of Management, 24(3), 299-315. 